\title{
The Halal Dietary System as a Recipe for Good Health
}

\author{
Waheed Azeez
}

\begin{abstract}
The global interest in halal diet is growing faster than ever. With the steady growth in the world Muslim population coupled with mass production of halal foods, this trend is expected to continue ad-infinitum. Many sources have declared Islam to be the fastest growing religion in the world. In 2008, the National Geographic published a report quoting a Vatican source that Islam has overtaken Catholicism to become the largest religion. With Muslims now at about 17.4 percent of the world population, it is understandable why the global quest for halal products continue to increase.

Interestingly, it is noted recently that non-Muslim consumers have also started to show interest in halal products. Most of those consumers often mention health factors as the main reason behind their choice of halal foods. While most Muslims mainly choose the halal diet to comply with the dictates of their religion, they also consider the health factors as an associated benefit.

The aim of this paper is to evaluate the halal dietary system and see whether it has any positive or negative effects on the health of the consumers. Our approach in this regard will be multifaceted as we will not focus only on the socio-religious factors, but also on various aspects of the discourse.
\end{abstract}

\section{Introduction:}

According to some sources, the halal food industry is one of the fastest growing niches in the global market today. With an estimated growth of $\$ 500$ billion, the global halal market was valued at $\$ 1.2$ trillion in 2010 constituting a fifth of world food trade. This contrasts greatly from its value of $\$ 580$ billion in 2003 .

This steady growth of the halal market has been so tremendous in the last decade that it has attracted the interests of governments and non-government organizations.

The struggle among the countries with large Muslim populations to outsmart each other in this trade further illustrates this trend. For instance, having recognized the potentials of the halal industry which has been forecast to grow by more than $20 \%$ over the next decade, the Malaysian government has been making efforts to firmly place the country in a vantage position and make Malaysia as the beacon of the global halal market. As one of the most advanced Muslim countries, Malaysia wishes to present itself as the international hub for the halal industry.

To achieve this objective, the country hosts what it calls Annual Halal Week which comprises various events such as International Halal Showcase (MIHAS), World Halal Research Summit (WHR) and World Halal Forum (WHF) with the single aim of expanding the growth of the global Halal industry through business matching, trade exhibition, forum and research. The program attracts thousands of participants around the world.

The United Arab Emirate also organizes similar events on a more regular basis through Gulfood. Unlike the Malysian events which are held annually in a grand style, Gulfood events are held in a regular and sustained manner attracting food vendors and entrepreneurs from around the world. Some of the programs featured in these events include, Halal Food Exhibition, Food Leaders Summit, FoodPreneur Forum, Food Processing and Packaging Forum and Franchise Workshop.

Apart from these two countries, all major Muslim countries use various means to make their own impact in this industry. For instance, Saudi Arabia's approach is to establish more culinary schools to train local chefs to international standard. In fact, the $17^{\text {th }}$ annual Saudi food, hotel and hospitality show held in Jeddah from May 20-23, 2012 attracted 350 companies from 22 countries around the world. The aim of the show is to establish Jeddah as the hub of the food, hotel and hospitality sector, and the Kingdom as a national showcase and forum where worldwide suppliers present their products and services. Pakistan also tries to make itself a regional player in this market by exporting its halal products to neighboring countries.

The Halal Research Council, in collaboration with PAMCO and Livestock \& Dairy Development Department, recently organized a conference on halal food in which scholars from over 15 countries present papers on the subject.

Even in countries where Muslims are in minority such as in Europe and America, the growth in the halal industry has made the government recognize the need to regulate this growing market. The government either does this by direct legislation or through general regulating agencies or by granting licenses to religious organizations or private businesses to do so on its behalf. The United States and the Netherlands are examples of the former while Britain and France are examples of the latter. 
Although, the halal industry covers various aspects such as food services, food processing, and logistics, pharmaceutical, cosmetic and personal care, hospitality and hotel services etc, attention is usually focused on food products especially meat and poultry. This is not unconnected with the significant position that food occupies in the human society. Apart from being the major source of energy and sustenance for man, food can equally be used for pastime and recreational purposes. Food is also used as a means of entertainment and hospitality. Despite all these benefits, food can also bring misery and instability to the human society. Access to food or lack of it often leads to misunderstandings and conflicts and is also used by powerful nations to punish or oppress the weaker ones.

Above all, food has been identified as a major source of diseases and deaths. Therefore, any system that is linked to what we eat must be closely investigated to identify any potential risk or hazard and find ways to avoid them. It is on this basis that this paper focuses mainly on the dietary aspect of the Halal to see what impacts it may have on the health of those who adopt this dietary regime.

\section{What is Halal}

When the word Halal is mentioned to most people living in the western countries, their minds will go to the Pakistani or Bangladeshi chicken and chip shops on the high streets or a particular brand of food specially produced by big supermarkets and sold to customers of Middle East and some Asian and North African countries. However, the word has a wider meaning and broader application.

Etymologically, the word halal is derived from the Arabic verb ahalla meaning to make lawful or permissible. Halal is the verbal noun which can also be used as an adjective to describe something as lawful or permissible. By and large, anything deemed permissible in Islamic Law is described as halal. The opposite of halal is haram. The term is used to denote what is prohibited or unlawful in Islam.

The principles of halal and haram are part of the whole legal system that constitutes the Shariah. This covers all aspects of human life and the dietary system is not an exception. As applied to any human activity, a Muslim is expected to evaluate the legal status of any food before eating it. The halal food is the food that is lawful for consumption while the forbidden one is haram.

It is the responsibility of every Muslim to distinguish the halal from the haram. To be able to do this, one needs to understand the basic principle of asl often translated as the original principle, which states that "lawfulness is the rule while prohibition is an exception." This principle of natural permissibility is derived from the Qur'an $(2: 29 ; 45: 13 ; 31: 20$ etc) and it postulates that everything on earth is created for man's use and he can use any of them for his own benefit unless otherwise indicated.

With regard to diets, the same rule applies. That means that any food should be considered originally permissible unless there is a clear expression or divine legislation establishing its prohibition. In Islam, the number of prohibited foods is very small and insignificant while the permitted ones are vast and numerous. Therefore, all a Muslim needs do is identify the few prohibited ones and apply the principle of natural permissibility on the rest.

Identifying prohibited foods described as haram is not difficult. These foods are specifically mentioned in the two major sources of Islamic law, namely the Qur'an and the Hadith. Qur'an (2:173 and 5:3) contains information about the types of animals that are forbidden for Muslims to eat. Mentioning of Allah's name on animals is prescribed also in the Qur'an (6:118-121). No requirement is made about the method of killing animals for food. Information regarding slaughtering is found in the Hadith. Both the Qur'an and the Hadith explicitly emphasize the prohibition of alcohol for Muslims. To sum it up, forbidden foods for Muslims are itemized below:

- $\quad$ pork or pork by-products

- animals that were dead prior to slaughtering

- animals not slaughtered properly or not slaughtered in the name of Allah

- blood and blood by-products

- alcohol

- carnivorous animals

The list may be shorter or longer depending on various Muslim sects or different schools of thought. However, majority of Muslims consider everything in the above list as haram, and therefore unlawful. Any other food outside the list is halal and is therefore approved for consumption.

\section{Halal Food and Health}

With the explanation given above, one can realise that it is super easy for any Muslim to distinguish the forbidden foods (Haram) from the lawful ones (Halal). In this section, we want to identify the health benefits in avoiding the haram food in favour of the halal ones. 


\section{Dead Animal:}

This is the most serious one among the prohibited foods in Islam. It is very central in the Islamic dietary system. It is on top of the list of prohibited foods mentioned in the Quran. This prohibition covers all types of animals that die through natural causes or is killed in any other way different from slaughtering which is the only method stipulated in Islam. This segment is further elaborated in the Qur'an 2:173.

Prohibition of dead animals can be seen as a preventive measure intended to protect the community from acquiring diseases from sick animals.

One may argue that modern societies, especially the developed countries, have a robust system that makes it very difficult if not totally impossible to eat, sell or serve animals that die naturally, we must remember that there still are countries today where such systems are not in place or not properly managed. In most of the poor countries, people still consider it proper to eat dead or visibly sick animals and they do not see anything wrong with it.

It is recommended for Muslims not to eat any animal if it appears to be sick. That makes it pertinent for animals to be checked properly before being killed for food to prevent people from contacting the diseases that make the animals sick in the first place. In the case of the dead animals, this may not be practically possible without rigorous procedure carried out by experts.

Common diseases associated with dead animals include; Campylobacteria (Campylobacter), Cryptosporidiosis (Cryptospodridium), Escherichia coli infection 0157:H7 (E.coli0157) and Hemolytic Uremic Syndrome (HUS), Salmonelosis (Salmonila).

We may not be able to elaborate further on the details of each of the diseases. But it suffices here to state that anyone who eats dead animals has a very high risk of contacting any of the above diseases and others not mentioned. Most of them are very dangerous and can lead to fatal consequences.

\section{Blood:}

Blood consumption is totally forbidden in Islam, not only because it is considered as najis (filth), but also because it is a major source of diseases. It is interesting to note that Islam is not the only religion that prohibits blood consumption. The practice cuts across all the three Abrahamic religions, namely Judahism, Christianity and Islam. There was complete unanimity among the Jews and the early Christians on this matter. Despite the initial controversy among the Apostles in the first century as to which parts of the Mosaic law were to be upheld, they all concluded that it was necessary to abstain from blood consumption as stated in the Bible thus:

For it seemed good to the Holy Ghost, and to us, to lay upon you no greater burden than these necessary things; That ye abstain from meats offered to idols, and from blood, and from things strangled, and from fornication: from which if ye keep yourselves, ye shall do well, Fare ye well. (King James Version - Acts, 15:28-29)

The wordings of the above passage of the Bible are very similar to that of the Quran on the same subject as stated below:

He has only forbidden to you dead animals, blood, the flesh of swine, and that which has been dedicated to other than Allah. But whoever is forced [by necessity], neither desiring [it] nor transgressing [its limit], there is no sin upon him. Indeed, Allah is Forgiving and Merciful. (Quran 2:173)

In essence, the main purpose behind this prohibition is not unconnected to human health and wellbeing. If we look at the mammalian blood circulatory systems, we would realise that a great number of pathogenic microorganisms may be present in the blood as it travels to different parts of the body. This is true of all mammals including man. But the most interesting part of it is that the microbes that are harmful to some animals may be harmless to others. By directly consuming the blood in any form, be it in solid or liquid form, one may be seeking a direct contact with disease causing agents which can be potentially dangerous.

Pork:

Also forbidden for Muslims is pork or pork products. This includes sausages, bacon and gelatine (if made from pigs) or any other products that contain even a small amount of swine.

Like blood consumption, the prohibition of swine is not only limited to Muslims. It is also forbidden among the Jews and that is why pork and its by-products are completely excluded in all kosher foods produced for the Jews. Even some Christian leaders believe that pork is not spiritually suitable for consumption by Christians. They base their argument on two passages of the Bible in which believers are advised to abstain from eating pork. Below are the relevant portions of the Bible on this matter:

"And the swine, though he divide the hoof, and be cloven footed, yet he cheweth not the cud; he is unclean to you".

"Of their flesh shall ye not eat, and their carcass shall ye not touch, they are unclean to you." [Leviticus 11:7-8] 
"And the swine, because it divideth the hoof, yet cheweth not the cud, it is unclean unto you. Ye shall not eat of their flesh, nor touch their dead carcass."

[Deuteronomy 14:8]

Be that as it may, we need to understand that the basis for the prohibition of pork in Islam is for healthy living. Pigs have been recognised as a very dirty and unclean animal. Besides, pork contains more fats than can be found in any other type of meat making pork eaters to be more susceptible to obesity and its related complications. With higher cholesterol level in their blood, regular pig eaters are also prone to asthereosclerosis, cardiovascular accidents and even sudden death. In addition, it has been scientifically confirmed that the animal's flesh and skin harbour some microorganisms that are very dangerous to human health. Despite the perceived advancement in piggery technology, no one has been able to device a method of completely expelling these pathogenic parasites.

\title{
Some of the diseases associated to pork include:
}

Trichnella Spratis (Trichia worms), Taenia Solium (Pork tape worm), Round Worm (e.g Ascaris causing obstructive jaundice), Hook Worm (e.g Ancylostomiasis - causing anaemia, oedema, heart failure, retarded growth, tuberculosis, typhoid and diarrhoea), Schitosoma Japonicum (causing bleeding, anaemia etc), Paragomines Westermeini (causing bleeding in the lungs called endenve haemoptysis), Pasiolepsis Buski (causing diarrhoea and oedema), Clonorchis Sinensis (causing obstructive jaundice and liver enlargement), Metastrongylus Aspri (causing bronchitis and abscess of the lungs), Gigathorinchus Gigas (causing digestive disorder and anaemia), Balatitidium Coli (causing acute dysentery and general weakness), just to mention but a few. New diseases continue to be discovered in pigs from time to time further confirming the inherent danger in pork eating.

For instance, in a recent collaborative study conducted in predominantly pork consuming part of Uganda, a high prevalence of a Non-Tuberculous Mycobacteria (NTM) was confirmed to be present among slaughter pigs in the area. As concluded in the report, the findings 'could be of a major public health concern within the studied community.

Before concluding this section, I need to state that the fact that pigs harbour pathogens in their bodies does not make them unuseful to man. The morphological and genetic resemblance that occurs between pigs and humans make their organs more suited for transplants. It is on this premise that scientist are working on cloning genetically modified pigs to enable them produce organs which can be harvested for human transplant. Without going into any moral or ethical arguments on this project, it is suffice here to state that pigs' flesh may not be too healthy for consumption; the use of their organs for transplant is an aspect that can be considered for further investigation.

\begin{abstract}
Alcohol:
One of the major achievements of Islam is its ability to eradicate alcoholism among its adherents. The menace of drug and alcohol misuse is becoming too difficult to manage in the modern society. Billions of dollars are committed by governments worldwide to put some systems in place that will force people into responsible drinking and reduce the associated deaths and sufferings. No nation has completely achieved this goal despite all the efforts put into it. Islam achieved this goal several centuries ago with a single stroke of legislation. In the Quran 5:90, the prohibition of alcohol to Muslims is established. In this verse, alcohol, among other things, is described as a handiwork of the devil and all Muslims are commanded to move away from it. Below is the relevant portion:

O you who have believed, indeed, intoxicants, gambling, [sacrificing on] stone alters [to other than Allah], and divining arrows are but defilement from the work of Satan, so avoid it that you may be successful.

In an account narrated by Abu Darda, the Prophet (SAW) described alcohol as the key to everything evil.

We must note at this juncture that the prohibition of alcohol in Islam covers all types of intoxicants and in any forms, be it in solid, liquid and gaseous forms. Inasmuch as it interferes with the mental functioning of the user, either temporarily or permanently. Therefore, substances such as Cocaine, Heroin, club drugs, Fentanyl, Inhalants, LSD (acid), MDMA (ecstacy), Methamphetamine, PCP/Phencyclidine, Steroids (anabolic), Marijuana, Opium, Speed and others like them, all stand forbidden in Islam. The negative impacts of these intoxicants on the health of the users cannot be overemphasised. One may question the stand of Islam on intoxicants by arguing that some of these intoxicants are useful for medical reasons. This fact has already been acknowledged in the Quran which is the most authentic source of Islamic Law thus:

"They ask thee concerning wine and gambling, say: "In them is great sin, and some profit, for men; but the sin is greater than the profit..."(Quran 2:219)

When we look at the myriad problems that alcohol and other intoxicants caused in our society today, we would realise that their disadvantages outweigh their advantages by far. We need to think of the number of patients
\end{abstract}


admitted daily in mental hospitals and rehabilitation centres across the globe; the number of road accidents that occur year in year out as a result of alcohol influences; the amount of money expended and time committed to fight alcohol related crimes as well as lives and property lost to such crimes.

For instance, a report published recently by the Institute of Alcohol Studies, mentions a study of 43 fatal falls in Frankfurt Germany which found that 23 of the deaths $(53 \%)$ were preceded by heavy drinking. Similarly, in the first brief of Alice RAP network's new series of policy papers, it is opined that one in eight deaths of people between the ages of 15 and 64 in Europe results from alcohol with the estimated cost of $300 €$ to the European economy.

The mental effects of alcohol must not preclude its negative effects on the physical health of the drinker. Ippolito (2003) studies the behaviour of heavy drinkers and found that while alcohol may be beneficial for populations that are deficient in their health for other reasons like smoking and poor eating, the populations who follow good diets benefit very little from alcohol.

Ippolito's submission is perfectly in tandem with the position of the Quran (2:219) that alcohol has some benefits but its disadvantages are more than its advantages. Apart from the issues we have raised above, the negative impacts of alcohol on the physical health of the drinker are something we should be worried about. After all, those who emphasise the benefits of alcohol often use the antioxidant contents of Red Wine as evidence to support their claim that alcohol consumption reduces cardiovascular disease. In response to this, Vogel (2002) has this to say:

Alcohol consumption reduces cardiovascular disease risk primarily by increasing production of high-density lipoprotein cholesterol, and possibly by increasing plasminogen, tissue plasminogen activator, and endothelial function, and decreasing platelet aggregability, fibrinogen, andlipoprotein (a) Red wine, containing antioxidants, has been purported to be especially cardioprotective. However, red wine consumption is not associated with reduced all-cause mortality in European countries, and American studies have found no relationship between the type of alcohol consumed and cardiovascular risk.

Furthermore, so many studies have linked alcohol to other debilitating diseases. For instance, Klasky (1996) confirms the relationships between alcohol consumption and various cardiovascular conditions corronary disease and hypertension. Similarly, Klastky in another study links incidences of hospitalisation for several types of cerebrovascular disease to heavy alcohol consumption.

In a report published by the Pan American Health Organisation in 2000, the burden of disease and death caused by alcohol in North America is highlighted. According to the report, alcohol consumption accounted for $4.8 \%$ of all the deaths and $9.7 \%$ of all daily loss in the year 2000 . To conclude this section, we consider it pertinent to refer to a publication of the National Institute of Alcohol Abuse and Alcoholism. The report mentions the most common diseases associated to alcohol use. We have managed to extract the relevant ones and summarized them below:

Cardiovascular Diseases: Hypertensive disease, Coronary heart disease, cerebrovascular disease, Ischemic stroke, hemorrhagic stroke and other CVD causes

Malignent Neoplasms: mouth and oropharynx cancers, esophagus cancer, liver cancer, other neoplasms, diabetes mellitus

Neuropsychiatric Conditions: unipolar major depression, epilepsy, alcohol use disorders,

Digestive diseases: Cirrhosis of the liver

In view of all the above, one does not need to struggle too much to conclude that taking a teetotal approach of the halal dietary system is the best way of avoiding the multifarious problems associated with alcohol consumption.

\section{More on Slaughtering:}

Slaughtering or killing an animal by cutting its throat is the most controversial aspect of the halal dietary system. Apart from forbidding specific animals for consumption, Islam further prescribes a method of killing the animals that are permitted for Muslims to eat. Slaughtering is the only killing method permitted to be adopted by Muslim in killing animals for food and the name of God must be invoked for the spiritual purification of the animal.

As explained above, this method is not clearly stated in the Qur'an. However, it is indirectly mentioned in a couple of places. An example is in Suratul-Bakarah (Chapter of the Cow) it is mentioned in relation to the divine order given to the people of Israel to slaughter a cow in sacrifice to Allah. In fact, the chapter takes its name from that section (verse 67) in which slaughtering is mentioned. Other places in which slaughtering is mentioned include the following:

Quran 34:107 \& 14:6 - In relation to Abraham and his sacrificial ordeal 
Quran 3:71 - In relation to the people of Israel

Quran 27:31- In relation to Solomon and his bird (Hudhud)

On the other hand, the hadith, is more explicit in this regard. The Prophet (SAW) did not only mention slaughtering as the only method approved for killing animals but also went further to make full description of how this slaughtering should be carried out. According to the hadith related by Muslim, the person slaughtering an animal is required to sharpen his blade properly and put the animal in a comfortable position before killing it. As said earlier, this method of killing has generated a lot of controversy in the modern time. While some see it as cruel and inhuman, others do not see anything wrong with it. Those who are against slaughtering base their argument on animal rights point of view. They consider cutting an animal's throat while alive as an act of extreme cruelty and callousness. According to them, if man does not like to end his life in a painful and distressful condition, why should he subject a poor animal into this grim condition?

It is not the aim of this paper to delve into such controversy. Our concern here is to find out if this method of killing has any impact on the health of the eater. But we need to quickly point out the rationale behind this method with respect to the condition of the animal being slaughtered. In doing this, lets consider the significance of the cerebral circulation to the sustenance of the nervous system in all mammals. We understand the function of the heart in the mammalian circulatory system and how the heart and the brain work together to keep the mammal alive. If the heart ceases to supply the oxygenated blood to the brain, the cerebral circulation will break down leading to stroke or death.

In the event of an animal being slaughtered, the main vessels carrying blood and oxygen to the brain are severed and the communication between the brain and the heart is cut off. Also, as the brain is starved of oxygen, the cerebral circulatory system cease to function leading to nervous breakdown. The animal becomes unconscious and eventually dies. All these will take place in seconds. The only pain that the animal suffers is effects of the blade on its throat before the vessels are severed. Animals killed in some other ways may suffer more pain as both the brain and the heart will still be functioning till the point of death.

Considering the health of the eater, we have explained earlier why blood consumption is forbidden. Therefore, as the animal is slaughtered, the heart will continue to pump blood even after the throat has been cut. As a result of this, the animal will be drained of blood leaving only the flesh and other parts that are permissible to eat. Therefore, a system that gets rid the blood to make sure that the flesh is safe to eat is more beneficial to health than the one that allows the blood to congeal and become trapped within the flesh itself.

\section{Summary and Conclusion}

In the foregoing, we have tried to identify implications of the halal dietary system on the health of those who adopt it. We started by presenting a general outlook of the halal market and the global scale and its potential for growth in future economies. This is followed with a working definition of the word halal and its significance to Muslims.

With references from the Quran and the Hadith, which are the two major sources of Islam, we explain how super easy it is for any Muslim to distinguish the forbidden (Haram) foods from the lawful ones (Halal). The forbidden foods are examined with the aim to identify the rationale behind their prohibition which we found to be inextricably linked to health risk.

Finally, we examined the reason behind slaughtering as prescribed in Islam and we explain with biological evidence that it is beneficial to both the slaughtered animal and the consumer.

\section{References}

[1]. Adbdul Rahman R. and Mohamed Z. (2011), Malaysian Halal food entrepreneurs perspective towards globalization - A conceptual framework (electronic copy), Social Science Reserch Network, New York

[2]. Al-Jauziyah I. (2003), Medicine of the Prophet, 2nd Edition New York, (Maktaba Dar-ul-Islam)

[3]. Al-Saabuunii M. A. (2007), Tafsir ayaatul-ahkaam, Vol.1 Daar al-Saabuunii, Cairo

[4]. Al-Qardawi Y. (nd), The Lawful and The Prohibited in Islam, American Trust Publication, Indianapolis

[5]. Billauer B.P. (2009), On Salmonella: You Say Tomato.... I Say Hogwash': Reflections on Bioterrorism and Pandemic Preparedness (electronic copy), Social Science Reserch Network,New York

[6]. Gonzalez C.G. (2011), Theoretical Perspectives Introduction: The Global Politics of Food, University of Miami Inter-American Law Review, Vol. 43, Miami

[7]. Havinga T (2010), Regulating Halal and Kosher Foods: Different Arrangements Between Stat, Industry and Religious Actors, Erasmus Law Review, Vol.1, Issue 4, Rotterdam

[8]. Ippolito R.A.(2003) The Health Effects of Alcohol: Do Controls for Demographics and Other Risky Habits Affect the Conclusions? George Mason Law \& Economics Research Paper No. 04-05, George Mason University, Virginia

[9]. Jürgen R., Gerhard G, Christopher T. S., and Maurizio T (2003), Alcohol-Related Morbidity and Mortality, Acohol Research and Health, (electronic version) National Institute of Alcohol Abuse and Alcoholism

[10]. Klatsky A.L (2003), Moderate Drinking andReduced Risk of Heart Disease, in Alcohol Research \& Health Vol. 27, No. 1 (electronic version), National Institute of Alcohol Abuse and Alcoholism

[11]. Sprenger R.A (2010), The Food Safety Handbook, Doncanster Highfield .co.uk Limited 
[12]. Techathuvanan C, Draughon F.A, D'Souza D.H. (2010) Loop-Mediated Isothermal Amplification (LAMP) for the Rapid and Sensitive Detection of Salmonella Typhimurium from Pork, in Journal of Food Science (Electronic Version) Volume 75, Issue 3, Institute of Food Tecnologists, Chicago

[13]. Vogel RA. (2002), Alcohol, heart disease, and mortality: a review, in Rev Cardiovasc Med. 3(1):7-1 (electronic version), US National Library of Medicine - National Institutes of Health, Bethesda

\section{Online sources:}

http://www.alicerap.eu/

http://www.ameinfo.com/256048.html

http://pubs.niaaa.nih.gov/publications/arh27-1/39-51.htm)Sprenger

http://faculty.clintoncc.suny.edu/faculty/michael.gregory/files/bio\%20102/bio\%20102\%20lectures/circulatory\%20system/c irculat.htm

http://halalfocus.net/2012/05/17/jeddah-to-host-major-food-hotel-hospitality-and-packaging-show/

http://www.halalrc.org/images/Research\%20Material/Books/Halal\%20Food\%20-\%20A\%20compelete\%20Book.pdf http://www.ias.org.uk/newsroom/uknews/2012/news180512/news180512.html

http://www.medterms.com/script/main/art.asp?articlekey=16212

http://queentije.hubpages.com/hub/Factsabouteatingpork

http://www.sbi.gos.pk/pdf/IHC(Malaysia)-2011.pdf 